\title{
PRE-BOMB RADIOCARBON VARIABILITY INFERRED FROM A KENYAN CORAL RECORD
}

\author{
Nancy S Grumet ${ }^{1}$ Thomas P Guilderson ${ }^{2}$ Robert B Dunbar ${ }^{3}$ \\ ABSTRACT. We report results from AMS radiocarbon measurements $\left(\Delta^{14} \mathrm{C}\right)$ in corals recovered off the coast of Kenya. \\ Bimonthly samples which span the pre-bomb era average $-51 \% \circ( \pm 3.7 ; n=43)$, when age and Suess effect are corrected, and \\ over the time of interest (1946-1954) do not exhibit any discernible seasonality. Relative to regional pre-bomb $\Delta^{14} \mathrm{C}$ values \\ in the western Indian Ocean, our results indicate ${ }^{14} \mathrm{C}$ enrichment off the coast of Kenya. Furthermore, the absence of a distinct \\ subannual $\Delta^{14} \mathrm{C}$ signal suggests that open and coastal upwelling is negligible off the coast of Kenya. Unlike pre-bomb values \\ south of the equator near Seychelles and Madagascar, our pre-bomb value are enriched by more than $10 \%$. The enrichment \\ of pre-bomb Kenyan $\Delta^{14} \mathrm{C}$ values relative to sites around Mauritius, northern Madagascar and Seychelles, suggest that the \\ influence of depleted $\Delta^{14} \mathrm{C}$ water transported in the SEC is limited to regions south of 3 to $4^{\circ} \mathrm{S}$.
}

\section{INTRODUCTION}

The intimate relationship between the Indian Ocean and the atmosphere is revealed in the seasonal reversal of the Indian-Asian monsoons. The monsoons develop primarily as a response to the large thermal gradients between the Asian continent and the Indian Ocean. During the Northern-Hemisphere winter, a high-pressure cell develops over the Asian land mass and contributes to the creation of the Northeast (NE) monsoon; the extremely cold and dry air masses over land force air from the northeast to the southwest and drive surface ocean circulation counter-clockwise in the northern Indian Ocean. In contrast, during the Northern-Hemisphere summer, the Asian land mass becomes very warm and a low-pressure cell develops and forms the Southwest (SW) monsoon. Strong southwesterly flow in the lower troposphere brings substantial amount of moisture to India and releases it as precipitation from June to September.

The influence of the monsoons on the Indian Ocean is seen in the reversals of the surface circulation and in the hydrological conditions of the surface waters to $10-20^{\circ} \mathrm{S}$. The northern and equatorial Indian Ocean circulation is especially complex with large seasonal variations and reversals in major current systems. For example, as a response to prevailing southwesterly flow in the lower troposphere during the SW monsoon, a northward flowing Somali Current (SC) is strongly developed as a continuation of the South Equatorial Current (SEC) and East African Coast Current (EACC) (Figure 1a). Recognized as the western boundary current that causes structural readjustment in the baroclinicity down to $1000 \mathrm{~m}$, the $\mathrm{SC}$ is responsible for strong upwelling along the northern coasts of Somali and Oman and the development of the Southern Gyre (SG) and Great Whirl (GW) during the SW monsoon (Luther 1999). Surface water flow is predominantly in an eastward direction. In contrast, during the NE monsoon, northeasterly winds develop causing surface waters north of the equator to flow to the west or southwest comprising the North Equatorial Current (NEC) north of the equator and at the equator, south-flowing water off the coast of Somalia together with the northflowing EACC feed the Equatorial Counter Current (ECC), which moves eastward across the Indian Ocean between $0^{\circ}$ and $8^{\circ} \mathrm{S}$ (Figure 1b) (Schott and McCreary 2001).

The complex oceanography in the northern and equatorial Indian Ocean, briefly described above, is responsible for regional differences in the strength and amount of upwelling of subsurface water. As

\footnotetext{
${ }^{1}$ Department of Geological and Environmental Sciences, Stanford University, Stanford, California 94305 USA. Email: ngrumet@leland.stanford.edu.

${ }^{2}$ Center for Accelerator Mass Spectrometry, Lawrence Livermore National Laboratory, Livermore, California 94551. Also at the Institute of Marine Sciences, University of California at Santa Cruz, Santa Cruz, California 65064 USA.

${ }^{3}$ Department of Geological and Environmental Sciences, Stanford University, Stanford, California 94305 USA
} 
a result, there is considerable spatial radiocarbon $\left(\Delta^{14} \mathrm{C}\right)$ variability in surface waters of the western Indian Ocean. This is illustrated in the regional deviations in the ${ }^{14} \mathrm{C}$ offset from atmospheric ${ }^{14} \mathrm{CO}_{2}$, referred to as the reservoir effect, of marine calcareous shells from the northern and equatorial Indian Ocean (Dutta et al. 2001; Southon et al. 2002). For example, Southon et al. (2002) illustrate that Arabian Sea upwelling significantly influences the western Indian Ocean pre-bomb $\Delta^{14} \mathrm{C}$ signal. The regional mean using Suess-corrected $\Delta^{14} \mathrm{C}$ values for the western Arabian Sea $(\mathrm{n}=8)$ is $-73 \pm 2.8 \%$, while waters farther from the upwelling region, such as those in the tropical Indian Ocean $(n=11)$ yield a regional mean of $-66 \pm 2.6 \%$ (Southon et al. 2002). The distribution of $\Delta^{14} \mathrm{C}$ inferred from carbonates can highlight regional differences in oceanographic processes (e.g., Moore et al. 1997).

Oceanographic measurements of $\Delta^{14} \mathrm{C}$, such as those conducted by Geochemical Ocean Section Study (GEOSECS), Indian Gaz Ocean (INDIGO), and World Ocean Circulation Experiment (WOCE) programs have been used to construct vertical profiles of $\Delta^{14} \mathrm{C}$ and have increased our understanding of intense monsoon driven upwelling that occurs off the coast of Somalia and the Arabian Coast (e.g. Ostlund and Stuiver 1980; Broecker et al. 1985; Bard et al. 1989; Key et al. 1996). While results from these programs have been extremely valuable, the profiles are subject to

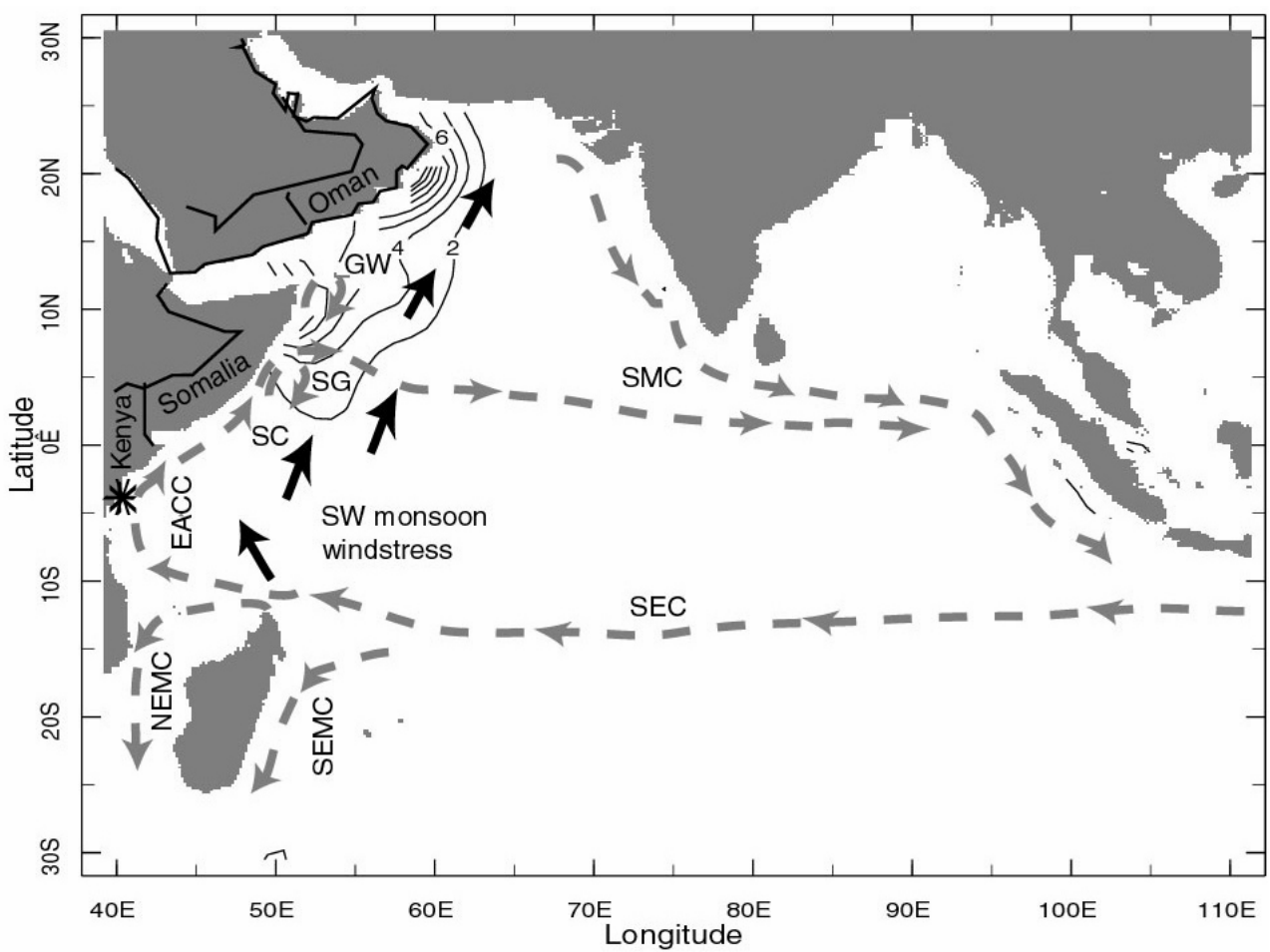

Figure 1a Coral cores were collected by drilling massive colonies of Porites lutea off the coast of Kenya, designated by a star, at Malindi ( $\left.3^{\circ} 14^{\prime} \mathrm{S}, 40^{\circ} 8^{\prime} \mathrm{E}\right)$, and Watamu ( $\left.3^{\circ} 23^{\prime} \mathrm{S}, 39^{\circ} 52^{\prime} \mathrm{E}\right)$. Summer (July-Aug.Sept.) surface $(<10 \mathrm{~m})$ nitrate concentrations are shown by contours intervals in $\mu \mathrm{mol} / \mathrm{L}$ (Conkright et al. 1998). Surface currents in the Indian Ocean during the SW monsoon: Somali Current (SC), East African Coast Current (EACC), Southwest Monsoon Current (SMC), South Equatorial Current (SEC), and Northeast and Southeast Madagascar Currents (NEMC and SEMC). Upwelling regions are associated with the Southern Gyre (SG) and Great Whirl (GW) (after Schott and McCreary 2001). Thick black arrows indicate predominant SW monsoon wind stress from the US National Centers for Environmental Prediction (NCEP) climatology for July. 
temporal aliasing since the measurements represent a "snapshot" of conditions. Such snapshots may be augmented with time series developed from $\Delta^{14} \mathrm{C}$ record from tropical corals.

${ }^{14} \mathrm{C}$ measurements from banded corals have been shown to represent $\Delta{ }^{14} \mathrm{C}$ levels of dissolved inorganic carbon (DIC) from the surrounding surface water (Druffel and Linick 1978; Druffel 1982). The accreted aragonite thus provides an unaltered record of ${ }^{14} \mathrm{C} /{ }^{12} \mathrm{C}$ ratios present in seawater (e.g. Druffel 1989; Brown et al. 1993; Guilderson et al. 1998; Guilderson et al. 2000). In this study we present the first continuous, bimonthly resolved time series of pre-bomb $\Delta^{14} \mathrm{C}$ measured in a coral from the western Indian Ocean. These results expand our knowledge of spatial resolution of ${ }^{14} \mathrm{C}$ reservoir corrections in the western Indian Ocean and add a time domain component to this valuable data set. Furthermore, the bimonthly sample resolution allows us to address questions regarding $\Delta^{14} \mathrm{C}$ variability attributed to the seasonally reversing monsoons. Ultimately, these combined efforts will aid in our understanding of regional oceanography as well as air-sea exchange rates in the Indian Ocean.

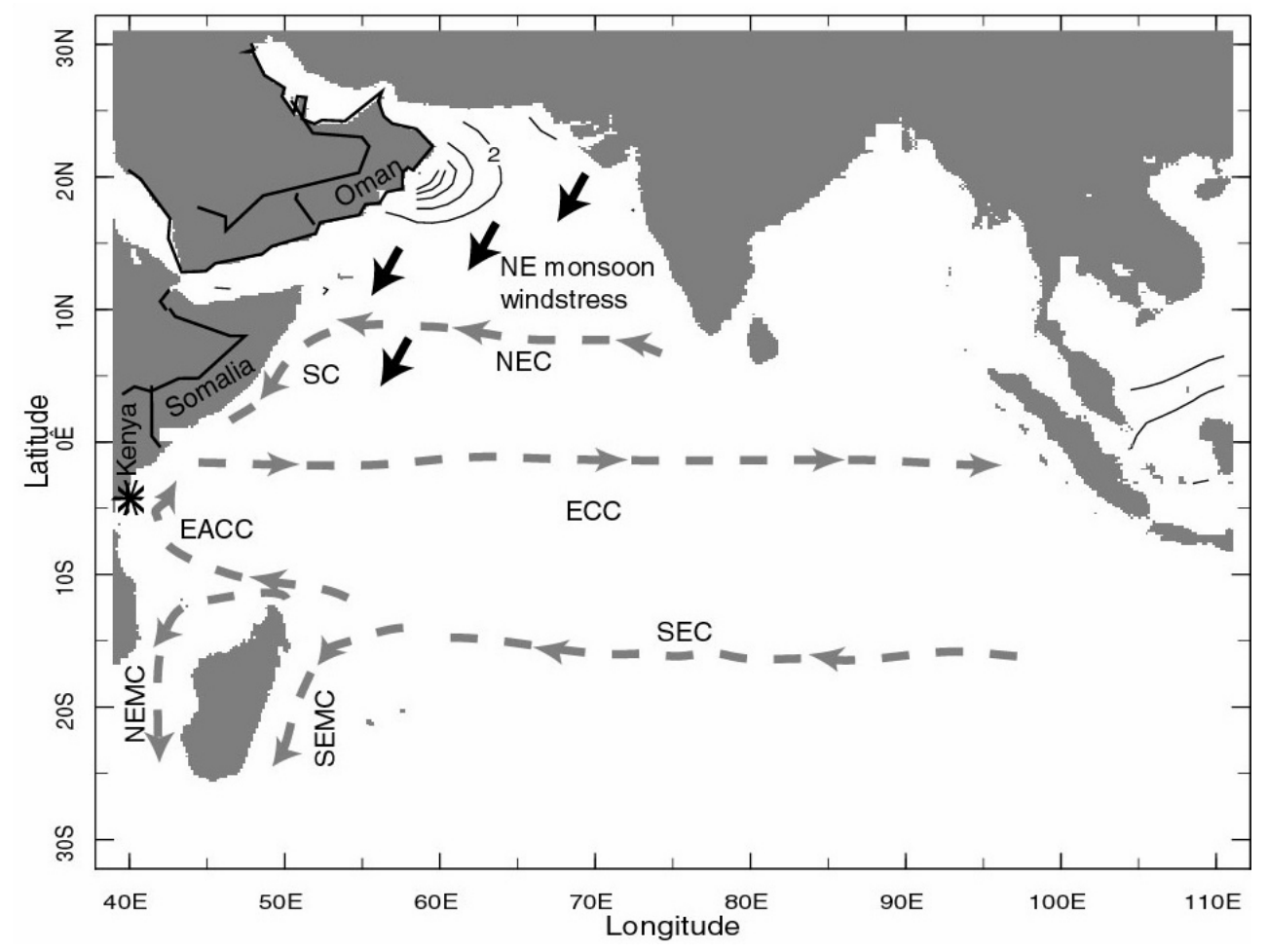

Figure 1b Coral cores were collected by drilling massive colonies of Porites lutea off the coast of Kenya, designated by a star, at Malindi $\left(3^{\circ} 14^{\prime} \mathrm{S}, 40^{\circ} 8^{\prime} \mathrm{E}\right)$, and Watamu $\left(3^{\circ} 23^{\prime} \mathrm{S}, 39^{\circ} 52^{\prime} \mathrm{E}\right)$. Winter (Jan.-Feb.March) surface $(<10 \mathrm{~m})$ nitrate concentrations are shown by contours intervals in $\mu \mathrm{mol} / \mathrm{L}$ (Conkright et al. 1998). Surface currents in the Indian Ocean during the NE monsoon: Somali Current (SC), East African Coast Current (EACC), North Equatorial Current (NEC), Equatorial Counter Current (ECC), South Equatorial Current (SEC), and Northeast and Southeast Madagascar Currents (NEMC and SEMC) (after Schott and McCreary, 2001). Thick black arrows indicate predominant NE monsoon wind stress from the US National Centers for Environmental Prediction (NCEP) climatology for January. 


\section{METHODS}

Cores collected from massive hermatypic corals Porites lutea off the coast of Kenya were sampled to assess the seasonal and spatial variability in the coral oxygen isotope $\left(\delta^{18} \mathrm{O}\right)$ and $\Delta^{14} \mathrm{C}$ signal (Figure 1a). Coral cores presented here were collected in 1996 from Kenya at Malindi $\left(3^{\circ} 14^{\prime} \mathrm{S}\right.$, $\left.40^{\circ} 8^{\prime} \mathrm{E}\right)$, and Watamu $\left(3^{\circ} 23^{\prime} \mathrm{S}, 39^{\circ} 52^{\prime} \mathrm{E}\right)$. The Malindi coral site is approximately $1 \mathrm{~km}$ offshore and at a depth of about $5 \mathrm{~m}$ at mean tide. It is an open coast patch reef site on a point. The Watamu coral is approximately $600 \mathrm{~m}$ offshore and $200 \mathrm{~m}$ landward of an intermittent barrier system. Water depth is about $7 \mathrm{~m}$ at the Watamu site. X-radiography of the cores reveals pronounced annual variations in skeletal density and growth rates range from 11 to $15 \mathrm{~mm} / \mathrm{yr}$. A transect was mapped along a prominent growth axis of the cores and sampled continuously from the top of the coral slab to approximately $626 \mathrm{~mm}$ in the Watamu core and between $325-375 \mathrm{~mm}$ in the Malindi core. Samples were collected using a low speed drill to extract aragonite powder every $2 \mathrm{~mm}$ for $\Delta{ }^{14} \mathrm{C}$ analysis ( $6 \mathrm{sam}$ ples per year) and $1 \mathrm{~mm}$ for $\delta^{18} \mathrm{O}$ analysis ( 12 samples per year).

Oxygen and carbon isotope measurements were analyzed at the Stanford University Stable Isotope Laboratory. Aliquots of coralline aragonite weighing 55 to $95 \mu \mathrm{g}$ were acidified with orthophosphoric acid at $70{ }^{\circ} \mathrm{C}$ and analyzed using a Kiel III carbonate device coupled to a Finnigan MAT 252 mass spectrometer. Approximately $15 \%$ of the samples were replicated, yielding an average standard deviation of less than $0.05 \%$ o for $\delta^{18} \mathrm{O}$ and $0.12 \%$ o for $\delta^{13} \mathrm{C}$. Unknowns were calibrated against a known standard NBS-19 (NIST SRM 8544) and with a Stanford in-house standard (SLS-\#1). All results are reported relative to the international V-PDB (Vienna Pee Dee Belemite) standard (Grumet et al. 2001).

Aragonite splits $\sim 10 \mathrm{mg}$ were hydrolyzed to $\mathrm{CO}_{2}$ in individual reaction chambers, evacuated, heated and acidified with orthophosphoric acid at $90{ }^{\circ} \mathrm{C}$. The resultant $\mathrm{CO}_{2}$ was converted to graphite in the presence of iron catalyst (Vogel et al. 1987). Graphite targets were measured at the Center for Accelerator Mass Spectrometry (CAMS) facility at Lawrence Livermore National Laboratory (LLNL) (Davis et al. 1990). ${ }^{14} \mathrm{C}$ results are reported as $\Delta{ }^{14} \mathrm{C} \%$ as defined by Stuiver and Polach (1977). These results include a minor background correction using a calcite standard and are $\delta^{13} \mathrm{C}$ and age corrected (Table 1). Concurrent analysis of an in-house standard yielded an external error of $\pm 3.7 \%$ o $(1 \sigma$, normalized to Fmodern $=1.0 ; n=23)$.

Well-developed annual density bands and minimum and maximum $\delta^{18} \mathrm{O}$ values, as well as a calibration period from 1990-1996, were used to define the chronology parallel to instrumental sea-surface temperature (SST) measurements (Grumet et al. 2001). Instrumental SST records indicate that the maximum (minimum) temperature off the coast of Kenya occurs in March/April (July/August). Accordingly, the minimum and maximum coral $\delta^{18} \mathrm{O}$ values were assigned the corresponding calendar date. Samples in between these points were linearly interpolated to make an age model. The assigned calendar months also show a strong correspondence to changes in density. The minimum $\delta^{18} \mathrm{O}$ values in April occur within the high-density bands, where calcification exceeds extension when the temperature is the warmest.

\section{RESULTS}

In our record, we sample the pre-bomb interval between 1947-1954 ( $n=43)$. The pre-bomb record suggests that a fossil fuel correction, known as the Suess Effect, of $14 \%$ o be applied to the age corrected data. This correction is based on back-casting the slope $\left(-0.23 \% \mathrm{yr}^{-1}\right)$ of the pre-bomb agecorrected data to 1890. However, work by Stuiver and Quay (1981) suggests that the slope of the fossil fuel effect is not constant between 1860-1950, primarily as a result of cosmic ray flux changes. 
Table 1 AMS $\Delta^{14} \mathrm{C}$ measurements of $\sim$ bimonthly Kenyan samples

\begin{tabular}{|c|c|c|c|c|c|}
\hline $\begin{array}{l}\text { Coral ID and } \\
\text { depth (mm) }\end{array}$ & Year & CAMS\# & $\begin{array}{c}\Delta^{14} \mathrm{C}[\% o] \text { age } \\
\text { corrected }\end{array}$ & \pm & $\begin{array}{c}\Delta^{14} \mathrm{C}[\% \circ] \\
\text { Suess corrected }\end{array}$ \\
\hline Watamu 96-534 & 1955 & 73533 & -625 & 26 & -511 \\
\hline Watamu 96-536 & 1954 & 73534 & -617 & 26 & -508 \\
\hline Watamu 96-538 & 1954 & 73535 & -581 & 27 & -472 \\
\hline Watamu 96-540 & 1954 & 73673 & -550 & 27 & -442 \\
\hline Watamu 96-544 & 1954 & 73674 & -597 & 28 & -490 \\
\hline Watamu 96-546 & 1954 & 73675 & -630 & 27 & -523 \\
\hline Watamu 96-550 & 1953 & 73676 & -629 & 28 & -522 \\
\hline Watamu 96-552 & 1953 & 73677 & -605 & 27 & -498 \\
\hline Watamu 96-554 & 1953 & 73678 & -624 & 27 & -518 \\
\hline Watamu 96-556 & 1953 & 73679 & -644 & 24 & -538 \\
\hline Watamu 96-560 & 1952 & 73680 & -624 & 29 & -519 \\
\hline Watamu 96-562 & 1952 & 67915 & -658 & 27 & -553 \\
\hline Watamu 96-564 & 1952 & 67916 & -642 & 27 & -537 \\
\hline Watamu 96-566 & 1952 & 67917 & -634 & 27 & -530 \\
\hline Watamu 96-568 & 1952 & 67918 & -617 & 33 & -513 \\
\hline Watamu 96-570 & 1952 & 67919 & -674 & 27 & -570 \\
\hline Watamu 96-572 & 1952 & 67920 & -588 & 27 & -484 \\
\hline Watamu 96-574 & 1951 & 67921 & -567 & 27 & -464 \\
\hline Watamu 96-576 & 1951 & 67922 & -590 & 27 & -487 \\
\hline Watamu 96-578 & 1951 & 67923 & -557 & 27 & -454 \\
\hline Watamu 96-582 & 1951 & 67924 & -644 & 26 & -542 \\
\hline Watamu 96-584 & 1951 & 67925 & -659 & 27 & -557 \\
\hline Watamu 96-586 & 1950 & 67926 & -670 & 27 & -569 \\
\hline Watamu 96-588 & 1950 & 67927 & -633 & 27 & -532 \\
\hline Watamu 96-590 & 1950 & 67928 & -612 & 30 & -510 \\
\hline Watamu 96-592 & 1950 & 67929 & -634 & 25 & -533 \\
\hline Watamu 96-594 & 1950 & 67930 & -605 & 28 & -505 \\
\hline Watamu 96-596 & 1950 & 67931 & -644 & 28 & -544 \\
\hline Watamu 96-598 & 1950 & 67932 & -647 & 35 & -547 \\
\hline Watamu 96-600 & 1949 & 67933 & -676 & 27 & -576 \\
\hline Watamu 96-602 & 1949 & 67934 & -573 & 30 & -474 \\
\hline Watamu 96-604 & 1949 & 67935 & -630 & 28 & -531 \\
\hline Watamu 96-606 & 1949 & 67936 & -620 & 31 & -521 \\
\hline Watamu 96-608 & 1949 & 67937 & -570 & 28 & -471 \\
\hline Watamu 96-610 & 1949 & 67938 & -597 & 28 & -499 \\
\hline Watamu 96-612 & 1948 & 67939 & -559 & 29 & -461 \\
\hline Watamu 96-614 & 1948 & 67940 & -580 & 24 & -482 \\
\hline Watamu 96-616 & 1948 & 67941 & -551 & 28 & -453 \\
\hline Watamu 96-618 & 1948 & 67942 & -471 & 28 & -374 \\
\hline Watamu 96-620 & 1948 & 67943 & -543 & 28 & -447 \\
\hline Watamu 96-622 & 1947 & 67944 & -631 & 28 & -535 \\
\hline Watamu 96-624 & 1947 & 74050 & -681 & 29 & -585 \\
\hline Watamu 96-626 & 1947 & 74051 & -664 & 31 & -568 \\
\hline Ma196 D2-325 & 1953 & 77066 & -585 & 22 & -474 \\
\hline
\end{tabular}


Table 1 AMS $\Delta{ }^{14} \mathrm{C}$ measurements of $\sim$ bimonthly Kenyan samples (Continued)

\begin{tabular}{|c|c|c|c|c|c|}
\hline $\begin{array}{l}\text { Coral ID and } \\
\text { depth (mm) }\end{array}$ & Year & CAMS\# & $\begin{array}{c}\Delta^{14} \mathrm{C}[\% o] \text { age } \\
\text { corrected }\end{array}$ & \pm & $\begin{array}{c}\Delta^{14} \mathrm{C}[\% o] \\
\text { Suess corrected }\end{array}$ \\
\hline Ma196 D2-327 & 1953 & 77067 & -627 & 27 & -516 \\
\hline Mal96 D2-330 & 1952 & 77068 & -612 & 27 & -502 \\
\hline Mal96 D2-333 & 1952 & 77069 & -654 & 27 & -544 \\
\hline Ma196 D2-335 & 1952 & 77070 & -602 & 27 & -492 \\
\hline Mal96 D2-3375 & 1952 & 77071 & -653 & 32 & -544 \\
\hline Mal96 D2-340 & 1952 & 77072 & -596 & 27 & -486 \\
\hline Mal96 D2-341 & 1952 & 77073 & -671 & 26 & -562 \\
\hline Mal96 D2-3435 & 1952 & 77074 & -572 & 24 & -463 \\
\hline Mal96 D2-347 & 1952 & 77075 & -621 & 34 & -513 \\
\hline Ma196 D2-349 & 1952 & 77076 & -644 & 26 & -535 \\
\hline Ma196 D2-351 & 1951 & 77077 & -688 & 25 & -580 \\
\hline Ma196 D2-354 & 1951 & 77078 & -672 & 32 & -564 \\
\hline Mal96 D2-3565 & 1951 & 77079 & -719 & 26 & -612 \\
\hline Mal96 D2-3595 & 1951 & 77080 & -647 & 30 & -539 \\
\hline Mal96 D2-3625 & 1951 & 77081 & -696 & 26 & -589 \\
\hline Mal96 D2-365 & 1951 & 77082 & -682 & 31 & -575 \\
\hline Mal96 D2-3675 & 1951 & 77083 & -712 & 26 & -605 \\
\hline Mal96 D2-370 & 1950 & 77084 & -720 & 26 & -614 \\
\hline Mal96 D2-3725 & 1950 & 77085 & -681 & 20 & -574 \\
\hline Mal96 D2-375 & 1950 & 77086 & -664 & 31 & -558 \\
\hline
\end{tabular}

For example, a change in atmospheric ${ }^{14} \mathrm{C}$ trend occurs around 1937 when the gradient changed from $-2.8 \%$ o to $-6.8 \%$ o. Given our limited data set, our back-casted slope most likely overestimates the Suess Effect. Furthermore, the short data set (7 years) can not capture changes associated with dynamic processes operating on an interannual to decadal time scale that are unrelated to the Suess effect. Therefore, we must look to model results and existing pre-bomb coral $\Delta^{14} \mathrm{C}$ time series from other sites in order to make an appropriate Suess correction.

The Suess Effect for the central gyres is 7-12\%o according to box diffusion models of Stuiver et al. (1986) and Oeschger et al. (1975). Druffel et al. (2001) measured a value of 7\%o at Hawaii and a range between 10-12\% for the Florida Keys (Druffel, 1997). Southon et al. (2002) made a fossil fuel correction in the Indian Ocean of 10\% (1910-1952) by combining model results from Stuiver et al. (1986) and pre-bomb coral samples (Druffel and Suess 1986). We believe a Suess correction of 10\%o is appropriate for the Watamu site given that waters reaching Watamu are relatively shallow (J Southon, personal communication; ERM Druffel, personal communication). All results reported below are age corrected as well as fossil fuel corrected.

Pre-bomb $\Delta{ }^{14} \mathrm{C}$ levels measured in the Watamu coral have a range between $-58 \%$ in boreal summer of 1947 to a maximum value of $-37 \%$ in boreal winter of 1948 (Figure 2a). Within the eight-year record, $\Delta^{14} \mathrm{C}$ levels average $-51 \%$ with a standard deviation of $\pm 4 \%$. The average annual range is $6 \%$, calculated as the difference between the minimum and maximum $\Delta^{14} \mathrm{C}$ value within a given year. In order to substantiate our findings from Watamu, we sampled a coral recovered nearby from Malindi. Between 1950 and 1953, Malindi $\Delta^{14} \mathrm{C}$ levels have a range between $-61 \%$ in the fall of 1950 to $-46 \%$ in the winter of 1952 (Figure $2 b$ ). The average Malindi $\Delta^{14} \mathrm{C}$ value is $-54 \%$ o with a standard deviation of $\pm 4 \%$. The average annual range is $7 \%$. 


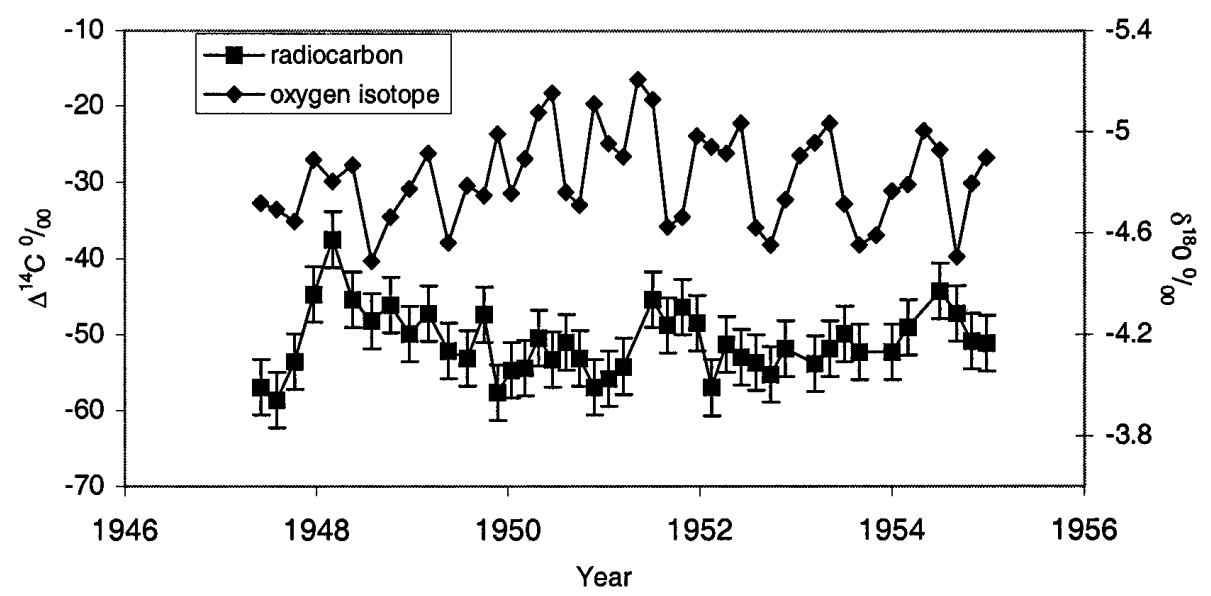

Figure 2a Radiocarbon and oxygen isotope time series from Watamu between 1947 and 1955. Pre-bomb $\Delta^{14} \mathrm{C}$ levels measured in the Watamu coral have an annual range between $-58 \%$ in boreal summer of 1947 to a maximum value of $-37 \%$ in boreal winter of 1948 . Radiocarbon levels average $-51 \%$ o with an average subannual range of $6 \%$.

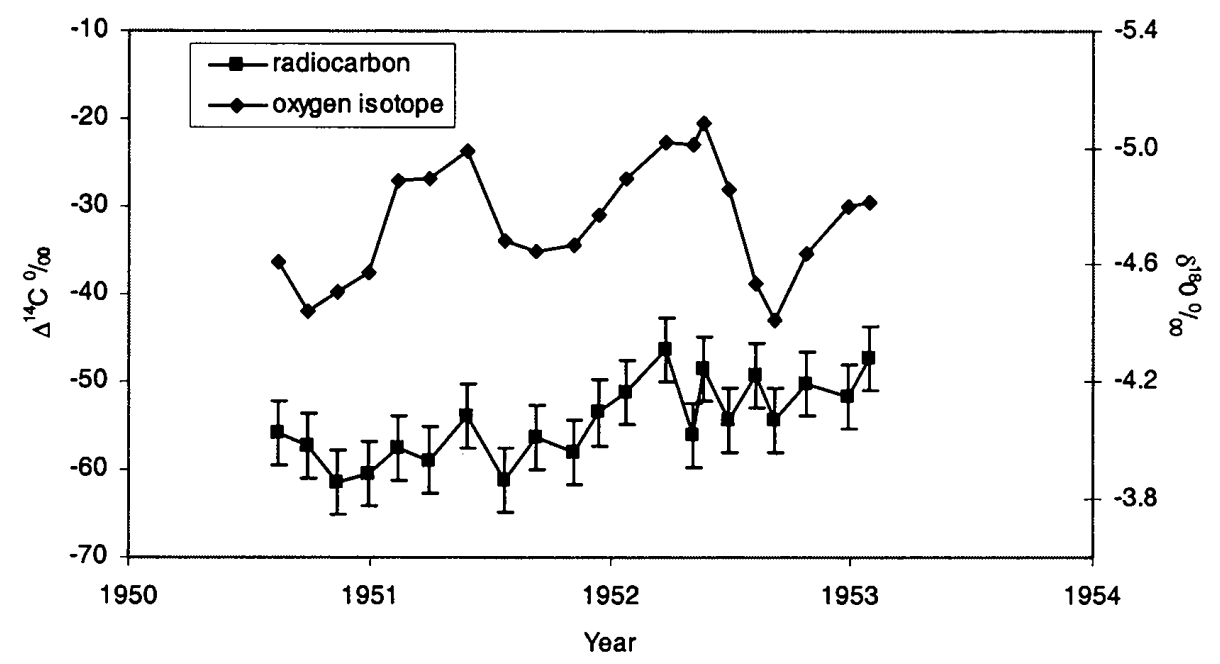

Figure 2b Radiocarbon time series from Malindi between 1950 and 1953. Between 1950 and 1953, Malindi $\Delta^{14} \mathrm{C}$ levels have an annual range between $-61 \%$ in the fall of 1950 to $-46 \%$ in the winter of 1952. The average Malindi $\Delta^{14} \mathrm{C}$ value is $54 \%$ with an average subannual range of $7 \%$.

\section{DISCUSSION}

The lack of a pronounced seasonal signal distinguishable from the analytical error in the Watamu and Malindi pre-bomb $\Delta^{14} \mathrm{C}$ records is consistent with the absence of local upwelling, either due to Ekman pumping driven by strong positive windstress curl or offshore deflection of surface waters by Ekman transport. These results are consistent by nutrient profiles. Profiles from GEOSECS (Spencer et al. 1982) in 1978 and WOCE (R Key, personal communication) in 1995 illustrate a relatively shallow thermocline but nutrient poor surface waters. Average phosphate concentrations in the surface waters $(<10 \mathrm{~m})$ off the coast of Kenya from annual LEVITUS94 data (Levitus et al. 1994) are 
$0.18 \mu \mathrm{mol} / \mathrm{kg}$ and nitrate concentrations are $0.15 \mu \mathrm{mol} / \mathrm{kg}$. In the upwelling regions of the Arabian Sea nutrient concentrations in the inshore coastal zone are elevated (nitrate is $18 \mu \mathrm{mol} / \mathrm{kg}$, phosphate is $1.48 \mu \mathrm{mol} / \mathrm{kg}$ ) (Woodward et al. 1999). Off the coast of Somalia, in the Great Whirl, nitrate concentration varies between 3 and $8 \mu \mathrm{mol} / \mathrm{kg}$ (Veldhuis et al. 1997). The effect of upwelling is to deliver nutrients and relatively depleted $\Delta^{14} \mathrm{C}$ to the upper water column, as observed off the coasts of Somalia and Oman. In contrast, reduced nutrient surface concentrations off the coast of Kenya and concurrent enrichment of $\Delta^{14} \mathrm{C}$ characterize the lack of coastal and nearby open-ocean upwelling in this region.

The lack of upwelling off the coast of Kenya is in stark contrast to the productive, vigorous upwelling regions north of the equator. As discussed earlier, the northward flowing Somali Current is responsible for upwelling along the northern coasts of Somali and Oman during the SW monsoon (Luther 1999). As a result, nutrient rich, depleted $\Delta^{14} \mathrm{C}$ water strongly influences this region. Southon et al. (2002) estimate a regional $\Delta^{14} \mathrm{C}$ mean of $-73 \pm 2.8 \%$ in the western Arabian Sea. In contrast, they calculated a mean of $-66 \pm 2.6 \%$ in the tropical southwestern Indian Ocean. Combining our results with previous work (Dutta et al. 2001; Southon et al. 2002), there is considerable spatial variability in pre-bomb $\Delta^{14} \mathrm{C}$ values in calcareous shells and corals from the western and northern Indian Ocean In many cases, the variability is due to differences in regional ocean circulation patterns discussed above.

Southon et al. (2002) suggest that the influence of monsoon-driven upwelling is propagated throughout the western Indian Ocean by the major current systems, especially the SEC. Relatively depleted $\Delta^{14} \mathrm{C}$ values from Sri Lanka (Ceylon) are consistent with this southeast transport of ${ }^{14} \mathrm{C}$-depleted Arabian Sea water (Southon et al. 2002). Eventually acting as a westward return flow, areas situated in the SEC pathway, such as Mauritius, northern Madagascar and Seychelles exhibit depleted pre-bomb $\Delta^{14} \mathrm{C}$ values. Southon et al. (2002) suggest that these values represent advection of ${ }^{14} \mathrm{C}$-depleted water into the SEC via southeasterly flow from the Arabian Sea. In contrast, our results from the western, equatorial Indian Ocean average $-51 \%$. These samples are enriched by more than $10 \%$ o compared to average southwestern Indian Ocean values reported by Southon et al. (2002). The influence of freshwater could raise the seawater $\Delta^{14} \mathrm{C}$ by either equilibrating with atmospheric $\mathrm{CO}_{2}$ or by increasing the stratification and reducing the amount of vertical mixing. However, the influence of freshwater at Watamu is negligible since the Mida Creek, which is near the coral site, is an ancient creek (McClanahan, personal communication). Furthermore, salinity values range between 33.5 and $36.6 \mathrm{ppt}$ (Obura 1995). These observations suggest that the Watamu site is fairly protected from riverine influence. If the SEC is a source of depleted $\Delta^{14} \mathrm{C}$, as Southon et al. (2002) propose, the northern limit of the SEC, and hence the influence of subsurface Indian Ocean water, is apparently south of our sites $\left(3-4^{\circ} \mathrm{S}\right)$. This enrichment therefore, suggests that westward return flow of water transported southeast from the Arabian Sea does not reach the surface waters surrounding the Kenyan coral sites, or alternatively there exist spatial-temporal biases in the discrete $\Delta^{14} \mathrm{C}$ measurements available.

\section{CONCLUSION}

Bimonthly Watamu coral $\Delta^{14} \mathrm{C}$ values between 1947 and 1955 averages -51\%o. In comparison, surface water pre-bomb $\Delta^{14} \mathrm{C}$ levels in the northern Indian Ocean are closer to $-73 \%$ o (Southon et al. 2002). Our results demonstrate that there is no immediate source of subsurface, $\Delta^{14} \mathrm{C}$ depleted water to the surface water off the coast of Kenya. Surface water nutrient concentrations are consistent with the lack of deeper water replenishment by upwelling in this region. The absence of a distinct subannual $\Delta^{14} \mathrm{C}$ signal suggests that coastal and nearby open-ocean upwelling are negligible. Furthermore, the enrichment of pre-bomb Kenyan $\Delta^{14} \mathrm{C}$ values relative to sites around Mauritius, northern Mada- 
gascar and Seychelles, suggest that the influence of depleted $\Delta^{14} \mathrm{C}$ water transported in the SEC is limited to regions south of 3 to $4^{\circ} \mathrm{S}$.

\section{ACKNOWLEDGMENTS}

We thank P Zermenko and D Mucciarone for analytical support and the Kenya Wildlife Service and Fithe Kenya Marine and Fisheries Research Institute for logistical and field support. This work was supported by a US DOE Global Change Education Program Fellowship to N S Grumet and a grant to R B Dunbar by NSF Climate Dynamics and Earth System History program grants OCE-9896157. $\Delta^{14} \mathrm{C}$ analyses were performed at the CAMS under the auspices of the US DOE by the UC, LLNL under Contract No. W-7405-Eng-48. $\Delta^{14} \mathrm{C}$ analyses were funded by the University of California's and LLNL's Exploratory Research in the Institutes (98-ERI-002 and 01-ERI-009). $\Delta^{14} \mathrm{C}$ data will be archived at the WDC-A paleoclimate archive in Boulder, Colorado. We thank an anonymous reviewer for constructive criticism and suggestions that helped to improve the manuscript.

\section{REFERENCES}

Bard E, Arnold M, Ostlund HG, Maurice P, Monfray P, Duplessy J-C. 1989. Penetration of bomb radiocarbon in the tropical Indian Ocean measured by means of accelerator mass spectrometry. Earth and Planetary Science Letters 87:379-89.

Broecker, WS, Peng T-S, Ostlund HG, Stuiver M. 1985. The distribution of bomb radiocarbon in the ocean. Journal of Geophysical Research 90:6953-70.

Brown TA, Farwell GW, Grootes PW, Schmidt FH, Stuiver M. 1993. Intra-annual variability of the radiocarbon content of corals from the Galapagos Islands. Radiocarbon 35(2):245-51.

Conkright M, Levitus S, O'Brien T, Boyer T, Antonov J, Stephens C. 1998. World Ocean Atlas 1998 CD-ROM Data Set Documentation. Technical Report 15. NODC Internal Report, Silver Springs, Maryland. 16 p.

Davis JC, Proctor ID, Southon JR, Caffee MW, Heikkinen DW, Roberts ML, Moore TL, Turteltaub KW, Nelson DE, Loyd DH, Vogel JS. 1990. LLNL/UC AMS facility and research program Nuclear. Instruments and Methods in Physics Research B 52:269-72.

Druffel EM, Linick TW. 1978. Radiocarbon in annual coral rings of Florida. Geophysical Research Letters 5:913-6.

Druffel EM, Suess HE. 1983. On the radiocarbon record in banded corals: exchange parameters and net transport of the ${ }^{14} \mathrm{CO}_{2}$ between atmosphere and surface ocean. Journal of Geophysical Research 88:1271-80.

Druffel EM. 1982. Banded corals: changes in oceanic ${ }^{14} \mathrm{C}$ during the Little Ice Age. Science 218:13-9.

Druffel ERM. 1989. Decade time scale variability of ventilation in the North Atlantic: high precision measurements of bomb in banded corals. Journal of Geophysical Research 94:3271-85.

Druffel ERM. 1997. Geochemistry of corals: Proxies of past ocean chemistry, ocean circulation, and climate. Proceedings of National Academy of Science 94: 8354-61.

Druffel ERM, Griffin S, Guilderson TP, Kashgarian M,
Southon J, Schrag DP. 2001. Changes in subtropical North Pacific radiocarbon and correlation with climate variability. Radiocarbon 43(1):15-25.

Dutta K, Bhushan R, Somayajulu BLK. 2001. $\Delta$ R correction values for the northern Indian Ocean. Radiocarbon 43(2A):483-8.

Grumet NS, Dunbar RB, Cole JE. 2001. Multisite record of climate change from Indian Ocean corals. 9th International Coral Reef Symposium, Bali, Indonesia. Forthcoming.

Guilderson TP, Schrag DP, Kashgarian M, Southon J. 1998. Radiocarbon variability in the western equatorial Pacific inferred from a high-resolution coral record from Nauru Island. Journal of Geophysical Research 103:24,641-50.

Guilderson TP, Schrag DP, Goddard E, Kashgarian M, Wellington GM, Linsley BK. 2000. Southwest subtropical Pacific surface water in a high-resolution coral record. Radiocarbon 42(2):249-56.

Key RM, Quay PD, Jones GA, McNichol AP, von Reden KF, Schneider R. 1996. WOCE AMS radiocarbon 1 Pacific Ocean results P6, P16 and P17. Radiocarbon 38(3):425-518.

Levitus S, Burgett R, Boyer T. 1994. World ocean atlas 1994. Volume 3: nutrients. Washington DC: NOAA Atlas NESDIS 3, US Department of Commerce.

Luther ME. 1999. Interannual variability in the Somali Current 1954-1976. Nonlinear Analysis 35:59-83.

Moore MD, Schrag DP, Kashgarian M. 1997. Coral constraints on the source of the Indonesian throughflow. Journal of Geophysical Research 102:12,359-65.

Obura D. 1995. Environmental stress and life history strategies, a case study of corals and river sediment from Malindi, Kenya. PhD dissertation. University of Miami.

Oeschger H, Siegenthaler U, Schotterer U, Gugelmann A. 1975. Box diffusion-model to study carbon-dioxide exchange in nature. Tellus 27:168-92.

Ostuland HG, Stuiver M. 1980. GEOSECS Pacific radio- 
carbon. Radiocarbon 22(1):25-53.

Schott FA, McCreary JP. 2001. The monsoon circulation of the Indian Ocean. Progress in Ocean. 51:1-123.

Southon J, Kashgarian M, Fontugne M, Metivier B, Yim WWS. 2002. Marine reservoir corrections for the Indian Ocean and Southeast Asia. Radiocarbon 44(1): $167-80$.

Spencer D, Broecker WS, Craig H, Weiss RF. 1982. Geosecs Indian Ocean Expedition. Volume 6, Sections and Profiles IDOE. National Science Foundation. $140 \mathrm{p}$.

Stuiver M, Polach HA. 1977. Discussion reporting of ${ }^{14} \mathrm{C}$ data. Radiocarbon 19(3):355-63.

Stuiver M, Quay PD. 1981. Atmospheric ${ }^{14} \mathrm{C}$ changes resulting from fossil fuel $\mathrm{CO}_{2}$ release and cosmic ray flux variability. Earth and Planetary Science Letters 53:349-362.

Stuiver M, Pearson GW, Braziunas TF.1986. Radiocarbon age calibration of marine samples back to 9000 cal BP. Radiocarbon 28(2B):980-1021.
Swallow JC. 1984. Some aspects of the physical oceanography of the Indian Ocean. Deep-Sea Research 31: 639-50.

Tomczak M, Godfrey, JS. 1994. Regional oceanography: an introduction. Oxford: Pergamon Press. $422 \mathrm{p}$.

Veldhuis MJW, Kraay GW, Van Bleijswijk GD, Baars MA. 1997. Seasonal and spatial variability in phytoplankton biomass, productivity and growth in the northwestern Indian Ocean: the southwest and northeast monsoon, 1992-1993. Deep-Sea Research I 44: 425-49.

Vogel JS, Southon JR, Nelson DE. 1987. Catalyst and binder effects in the use of filamentous graphite for AMS. Nuclear Instruments and Methods in Physics Research B 29:50-6.

Woodward EMS, Rees AP, Stephens JA. 1999. The influence of the southwest monsoon upon the nutrient biogeochemistry of the Arabian Sea. Deep-Sea Research II 46:571-91. 